\title{
Pohjois-Karjalan läänin aikuiskoulutuksen suunnittelusta
}

\author{
Rättyä, Esa. 1982. Pohjois-Karjalan lääni aikuiskoulutuksen suunnittelusta. Aikuis- \\ kasvatus 2, 1, 25-28. - Artikkeli on katsaus Pohjois-Karjalan läänissä harjoitettuun \\ aikuiskoulutuksen suunnitteluun, joka aloitettiin läänintasolla 1979. Läänissä on saatu \\ valmiiksi aikuiskoulutuspalveluiden kartoitus sekä selvitetty toiminnan puutteita ja on- \\ gelmia. Parhaillaan toteutetaan seitsemää erilaista kokeilu- ja kehittämisprojektia. Ar- \\ tikkelissa todetaan suunnittelun etenemisen kannalta perustavanlaatuiseksi ongelmaksi \\ kokonaisnäkemyksen muodostaminen siitä millainen tulevaisuus meillä on edessämme.
}

\section{Hankkeen käynnistyminen}

Pohjois-Karjalan läänissä on lääninhallituksen toimesta aloitettu koko läänin kattava aikuiskoulutuksen uudistamishanke. Paineita aikuiskoulutuksen suunnitteluun syntyi jo keväällä 1978, jolloin keskiasteen koulutuksen toimeenpanosuunnittelu oli alkuvaiheessa. Tällöin todettiin, että esimerkiksi ammattikurssitoiminta liittyy niin kiinteästi keskiasteen ammatilliseen koulutukseen, että sitä on vaikea jättää ottamatta huomioon tätä koulutusta suunniteltaessa.

Toiseksi aikuiskoulutuksessa nähtiin eräitä puutteita ja ongelmia läänin asukkaiden koulutuspalvelujen ja läänin elinkeinoelämän kehittämisen kannalta. Jo alkuvaiheessa kouluosastossa käytyihin keskusteluihin osallistuivat sekä ammattikurssikeskuksen että työvoimahallinnon edustajat. Samoihin aikoihin valtioneuvosto antoi päätöksensä niistä periaatteista, joita valtakunnan aikuiskoulutuksen suunnittelussa ja kehittämisessä on noudatettava. Tämä päätös otettiin huomioon aikuiskoulutuksen suunnittelun tehtäväkenttää hahmoteltaessa.

Lisää vauhtia läänin aikuiskoulutuksen suunnittelu sai maaliskuussa 1979, jolloin maaherra asetti suunnittelua varten läänin aikuiskoulutuksen uudistamistyöryhmän (AKUtyöryhmä). Työryhmän tehtäväksi tuli selvittää läänin aikuisten saaman koulutuksen nykytilannetta, koulutusresursseja ja -tarvetta sekä tehdä ehdotuksia aikuiskoulutuksen kehittämiseen liittyvien kokeilujen ja muiden kehittämistoimintojen aloittamisesta. Toimeksiannon mukaan kaiken suunnittelutyön tuli tapahtua em. valtioneuvoston periaatepäätöksen suunnassa sekä tiiviissä yhteistyössä valtakunnan tasolla tapahtuvan aikuiskoulutuksen suunnittelun kanssa.
Suunnittelutyön alkuvaiheessa päällimmäisenä olivat nimenomaan ajankohtaiset puutteet ja ongelmat, joiden korjaamiseen olisi ryhdytty, vaikka valtakunnallista suunnittelua ei olisi lainkaan käynnistetty.

\section{Suunnittelun voimavarat}

Kun asiaa lähdettiin pohtimaan, todettiin monien eri tahojen läänissämme olevan kiinnostuneita aikuiskoulutuksen kehittämisestä. Näiksi tahoiksi määriteltiin lääninhallituksen kouluosaston lisäksi kaikki aikuiskoulutusta antavat oppilaitokset Joensuun korkeakoulu mukaanluettuna, erilaiset järjestöt ja työvoimahallinto. Katsottiin, että aikuiskoulutuksen kehittämistoimenpiteiden suunnittelu tulee suorittaa yhteistyössä kaikkien niiden tahojen kanssa, jotka käytännössä vaikuttavat koulutuksen toteutukseen. Tästä syystä myös maaherran asettamassa työryhmässä on edustajia lääninhallituksen lisäksi eri oppilaitoksista, Joensuun korkeakoulusta ja työvoimahallinnosta. Viranomaisten yhteistyötä ei periaatteessa ole missään kielletty ja näin ollen sitä voidaan tehdä täsmälleen niin paljon kun halutaan ja ehditään. Sihteerityövoimaa on saatu $\mathrm{mm}$. virastotyöntekijöiden muodossa, ammatillisten oppilaitosten kuntainliiton palkkaamana sekä osa sihteerityöstä on tehty virkamiestyönä lääninhallituksessa.

Opetusministeriöltä on anottu pariinkin otteeseen suunnittelumäärärahaa, mutta sitä ei ole saatu. Näin ollen voidaan sanoa, että Pohjois-Karjalassa käytetyt suunnitteluresurssit ovat periaatteessa olemassa jokaisessa läänissä. 


\section{Suunnittelun sisältö ja organisointi}

Alkuvaiheessa suunnittelutyö painottui seuraaville osa-alueille:

1) läänin asukkaiden saaman aikuiskoulutuksen nykytilanteen sekä määrällinen että laadullinen kartoitus,

2 ) läänin aikuiskoulutusjärjestelmässä esiintyvien puutteiden ja ongelmien kirjaaminen ja

3 ) ajankohtaisten puutteiden korjaamiseksi ja ongelmien ratkaisemiseksi tehdyt aloitteet.

Kahdesta ensinmainitusta kohdasta on valmistunut kolme osaraporttia. Näistä ensimmäinen (1980), nykytilanteen kartoitus on laajin ja siinä pyritään vastaamaan kysymyksiin: miten paljon ja millaista aikuiskoulutusta pohjoiskarjalainen ihminen saa, mitkä tahot tätä koulutusta järjestävät ja millaisiin henkilöryhmiin se erityisesti kohdistuu. Toinen osaraportti valmistui 1981 ja se sisältää läänin aikuiskoulutukseen liittyviä selvityksiä, suunnitelmia ja kokeiluja. Toinen osaraportti koostuu seuraavista erillisselvityksistä:

- kansanopiston merkitys nuorille,

- kansalaisopiston merkitys nuorille,

- Joensuun korkeakoulun ulkopuolelle syksyllä 1979 jääneiden ylioppilaiden seuranta,

- ylioppilaiden kotitalouskoneasentajakurssi Pohjois-Karjalan ammatillisessa kurssikeskuksessa ja

- työttömien työnhakijoiden ammatillisen esikurssin käyneiden yleissivistävä pohjakoulutus.

Lisäksi raportti sisältää suunnitelmat metallialan jatkokoulutuksen opetussuunnitelmakokeilusta sekä yleissivistävän pohjakoulutuksen täydentämisen tehostamiseen tähtäävästä kokeilutoiminnasta. Kolmannen osaraportin valmistaminen käynnistyi lääninsuunnittelun kanssa käytyjen neuvottelujen pohjalta. Se sisältää selvityksen Pohjois-Karjalan kylätoimikuntien käsityksistä ammatillisen aikuiskoulutuksen tarpeesta. Raportti valmistui syksyllä 1981.

Läänin aikuiskoulutuksen uudistamistyöryhmä (AKU-työryhmä) on tehnyt toimintansa aikana useita aloitteita oppilaitoksille aikuiskoulutusjärjestelmässä esiintyvien puutteiden, esim. koulutusaukkojen korjaamiseksi. Näiden aloitteiden pohjalta on käynnistetty koulutusta ammattikurssikeskuksessa ja muissa ammatillisissa oppilaitoksissa.
Runsaan vuoden aikana suunnittelutehtäviä on järjestelty osaprojekteiksi, kytketty entistä tiiviimmin linjahallintoon niin ammattikasvatushallituksen kuin kouluhallituksenkin normaaliin kehittämistoimintaan sekä pyritty enenevässä määrin yhteistyöhön aikuiskoulutuksen valtakunnallisten suunnitteluelinten kanssa. Seuraavassa esitellään lyhyesti tällä hetkellä meneillään olevat osaprojektit sekä niiden toiminnan organisointi.

\subsection{Outokummun Opiston kokeilu}

Jo suunnittelun alkuvaiheessa havaittiin, että aikuisväestössämme on vielä verrattain paljon sellaisia henkilöitä, joiden ammatillisten opintojen esteenä on puuttellinen yleissivistävä koulutus. Tällaista opetusta näytti olevan läänin opistoissa saatavissa runsaasti. Ennakkokäsityksen mukaan näyttikin siltä, että tätä opetusta ei haluta käyttää hyväksi. Tutkittaessa lähemmin syitä, niiden todettiin jakautuvan seuraaville osa-alueille:

- koulutuksen tarvitsijoilla ei ole ollut riittävästi tietoja oman paikkakunnan koulutusmahdollisuuksista,

- opiskelun käytännön järjestelyt ja opiskelumuodot eivät aina ole vastanneet opiskelijoiden odotuksia ja edellytyksiä tästä johtuen opiskelu on keskeytynyt ja

- monilla henkilöillä on esteenä ollut työ tai perheestä johtuvat ongelmat, kuten esimerkiksi lastenhoidon järjestäminen.

Kouluhallituksen kanssa käydyn neuvottelun pohjalta päätettiin ongelmaa selvittää ja tilannetta parantaa kahdella eri tavalla. Ensiksi tehostettiin yleissivistävän pohjakoulutuksen täydentämismahdollisuuksia koskevaa informaatiota. Toiseksi päätettiin anoa kouluhallitukselta kokeilulupaa Outokummun Opistolle yleissivistävän pohjakoulutuksen problematiikan kokonaisvaltaiseksi selvittämiseksi. Outokummun Opiston kokeilu on sikäli merkittävä, että siinä seurataan opiskelijaa koko koulutuksen ajan ja vielä sen jälkeen selvitetään, mitä hyötyä opiskelijalle yleissivistävän pohjakoulutuksen täydentämisestä on ollut. Kokeilu alkoi syksyllä 1980 ja se päättyy 1983 .

\subsection{Metallialan jatkokoulutuksen opetussuunnitelmakokeilu}

Yleisen ammattikoulun tavoitteena on antaa ammattiopetusta siinä laajuudessa, että oppilaat määrätyn ajan asianomaisessa ammatissa työskenneltyään voivat saavuttaa ammattitai- 
toiselta työntekijältä vaadittavan pätevyyden. Myös keskiasteen ammatillisen koulutuksen uudistamisen jälkeen koulutus valmistaa nuoret ns. koulutusammattiin, mikä merkitsee sitä, että työammatin edellyttämät valmiudet hankitaan ammatillisen peruskoulutuksen jälkeen joko työssä tai jatkokoulutuksen avulla. Metallialan jatkokoulutuksen opetussuunnitelmakokeilu lähti liikkeelle siitä ajatuksesta, että jatkokoulutuksella voidaan lyhentää varsinaiseen työammattiin sopeutumisaikaa. Tätä tarkoitusta varten valmistettiin Pohjois-Karjalan ammatillisessa kurssikeskuksessa yhteistoiminnassa ammattikasvatushallituksen kanssa opetussuunnitelma metallialaa varten. Tätä suunnitelmaa ollaan nyt kokeilemassa jo toisella oppilasryhmällä. Kokeilu päättyy syksyllä 1982 jolloin tehdään lopulliset johtopäätökset. Kokeilun ensimmäinen väliraportti valmistui 1981, ja se luovutettiin ammattikasvatushallitukselle. Ammattikasvatushallitus on nimennyt kokeilun seurantaa ja johtamista varten työryhmän.

\subsection{Lyhytmuotoisen ammatillisen täydennyskoulutuksen tehostaminen}

AKU-työryhmä teki 1980 lyhytmuotoista ammatillista täydennyskoulutusta koskevan aloitteen Pohjois-Karjalan ammatillisten oppilaitosten kuntainliitolle. Kuntainliiton liittohallitus asetti asian selvittämistä varten toimikunnan, jonka esityksen pohjalta oppilaitosten kuntainliitossa on noin vuoden verran järjestetty lyhytmuotoista ammatillista täydennyskoulutusta budjettivuonna 1981 yhteensä yli 30 eri kurssia. Kuntainliiton talousarviossa on tätä tarkoitusta varten ollut määrärahaa vuonna 1981 noin 600.000 markkaa. Koulutusta järjestetään periaatteessa kaikissa kuntainliiton ammattikouluissa, kotiteollisuuskoulussa ja ammattikurssikeskuksessa. Tämän hetkisten näkymien mukaan koulutus tulee vuonna 1982 entisestään lisääntymään. Koulutus on tarkoitettu jo työssäoleville ihmisille ja sen vuoksi se on aika pitkälle erityiskysymyksiin suuntautuvaa ja toteutus tapahtuu pääasiassa iltaisin. Koulutusta suunnittelee kuntainliitossa tätä tarkoitusta varten erikseen palkattu koulutussuunnitelija.

\subsection{Kuntakohtaisen aikuiskoulutuksen kehittämisprojekti}

Seuraavina esiteltävät projektit ovat vasta alkuvaiheessa. AKU-työryhmä teki Lieksan kaupunginhallitukselle aloitteen kuntakohtai- sen aikuiskoulutuksen kehittämisprojektin käynnistämisestä Lieksan kaupungissa. Lieksan kaupunginhallitus asetti 1981 tarkoitusta varten toimikunnan. Lieksan kaupungissa toteutettavan kuntakohtaisen aikuiskoulutuksen kehittämisprojektin tavoitteena on

1) selvittää Lieksan kaupungin asukkaiden saaman aikuiskoulutuksen määrä ja laatu,

2 ) selvittää, miten kaupungin asukkaiden saama aikuiskoulutus vastaa koulutustarpeita

a) asukkaiden itsensä käsityksen mukaan ja

b) elinkeinoelämän näkökulmasta,

3 ) selvittää, mitä ongelmia kunnan alueella toteutettavan aikuiskoulutuksen järjestämisessä esiintyy sekä

4 ) tehdä ehdotus aikuiskoulutuksen määrällisestä, laadullisesta, organisatorisesta ja hallinnollisesta kehittämisestä Lieksan kaupungissa.

Läänin AKU-työryhmän välityksellä Lieksan projekti pitää yhteyttä myös valtakunnalliseen aikuiskoulutuksen suunnitteluun ennen kaikkea kuntakohtaista aikuiskoulutusta suunnittelevaan toimikuntaan sekä ammatillista lisäkoulutusta suunnittelevaan toimikuntaan. Lieksan kaupunki on palkannut toimikunnalle päätoimisen sihteerin ja toisena sihteerinä toimii henkilö lääninhallituksen kouluosastosta.

\subsection{Järjestömuotoisen koulutuksen projekti}

Järjestömuotoisen aikuiskoulutuksen osaprojekti on toinen äskettäin käynnistyneistä hankkeista. Sen tavoitteena on selvittää läänissä tapahtuvan järjestömuotoisen aikuiskoulutuksen tarvetta, sen järjestämisessä esiintyviä ongelmia sekä järjestömuotoisen ja muun aikuiskoulutuksen välisiä yhteistyömahdollisuuksia. Lääninhallituksen kouluosasto asetti tarkoitusta varten työryhmän, jossa on lääninhallituksen edustajan lisäksi edustus kaikista läänissä toimivista opintokeskuksista. Työryhmällä on tarkoituksena työskentelyn alkuvaiheessa ottaa yhteyttä opetusministeriön asettamaan järjestömuotoisen koulutuksen toimikuntaan.

\subsection{Aikuiskouluttajien täydennys- koulutuskokeilu}

AKU-työryhmän toimesta valmisteltiin syksyllä 1981 suunnitelma aikuiskouluttajien täydennyskoulutuskokeilun järjestämisestä. Kansalaisopistoissa toimii paljon tuntiopettajia, 
joista vain harvat ovat saaneet alan vaatimaa pedagogista erikoiskoulutusta. Myöskään vakinaisella päätoimisella opettajistolla ei ole mahdollisuutta virka- ja työehdosopimuksen mukaiseen täydennyskoulutukseen eikä opetuksen ohjaustoimintaa näissä oppilaitoksissa järjestetä. Tarve täydennyskoulutukseen on siten kaikilla opettajilla suuri.

Anomus kokeilun aloittamisesta on tällä hetkellä kouluhallituksen käsiteltävänä. Laaditun kokeilusuunnitelman mukaan kokeilun tavoitteena on

- selvittää, kuinka paljon ja millaista täydennyskoulutusta opettajat tarvitsevat,

- millaista yhteistyötä lääninhallituksen, korkeakoulun ja kansalaisopistojen välillä tarvitaan koulutuksen suunnittelussa ja järjestämisessä,

- millaisia muutoksia tarvitaan voimassaoleviin virka- ja työehtosopimuksiin,

- miten olemassa olevaa peruskoulun ja lukion lääninkouluttajajärjestelmää voidaan hyödyntää mainittua koulutusta järjestettäessä ja

- millaisia uusia lääninkouluttajia tarvitaan.

Mikäli kouluhallitus hyväksyy kokeiluanomuksen ja sen liitteenä olevan kokeilusuunnitelman, kokeiluun osallistuvien kouluttajien koulutus aloitetaan jo keväällä 1982 ja varsinainen täydennyskoulutus syksyllä 1982 .

\subsection{Maatalouden kurssitoiminnan kehittäminen}

Lääninhallituksen erikseen asettaman työryhmän toimesta on selvitetty maatalouden kurssimuotoisen koulutuksen kehittämistä. Työryhmän tekemien ehdotusten toteuttaminen monipuolistaa Pohjois-Karjalan ammatillisen kurssikeskuksen järjestämää koulutusta sekä parantaa sen organisaation toimivuutta. Työryhmä painottaa myös maatalouden koulutuksen suunnittelun koordinointia ja esittää tätä tarkoitusta varten maatalouskeskuksen asettaman työryhmän täydentämistä siten, että siihen tulee mukaan läänin alueelta kaikki alan koulutuksen suunnitteluun osallistuvat tahot. Suurin osa työryhmän ehdotuksista on välittömästi toteutettu, esimerkiksi Pohjois-Karjalan ammatillinen kurssikeskus on aloittanut verrattain laajamittaisen maatalouslomittajien koulutuksen läänin kunnissa.

\section{Suunnittelun jatkuminen}

Edellä on esitetty käytännön toimenpiteitä, joihin suunnittelun perusteella on koulutuksen kehittämisessä ryhdytty. Lisäksi yli kolme vuotta kestäneellä suunnittelutyöllä on luotu mielestäni hyvä valmius yhteistyössä tapahtuvaan suunnitteluun. Saadut kokemukset antavat viitteitä siitä, millä tavalla aikuiskoulutuksen suunnittelu tulisi läänikohtaisesti järjestää.

Tärkein ja vaikein suunnittelutyö on kuitenkin edessäpäin. On aivan ilmeistä, että työn koossapitämiseksi lääninhallitus tarvitsee yksinomaan tätä tarkoitusta varten palkattua työvoimaa.

Ehkä suurin ongelma jatkosuunnittelussa syntyy siitä, että se maailmankuva ja elämänmuoto, johon tähän saakka olemme ihmisiä kouluttaneet, on hiljalleen hajoamassa. Maapallon luonnonvarat eivät anna mahdollisuutta jatkuvan kasvun ajatukselle rakentuvan elinkeinoelämän jatkamiselle. Jo lähitulevaisuudessa joudumme hyvin kriittisesti tarkastelemaan, mitkä asiat nykyisessä elämänmuodossamme ovat ihmisen perustarpeiden tyydyttämisen kannalta välttämättömiä ja mitkä taas sellaisia, joihin tarpeet on synnytetty keinotekoisesti tarkoituksena tuotannon jatkuvan kasvun ylläpitäminen. Järkevä luonnonvarojen käyttö sekä ihmisen työnteon ja koko elämän mielekkyyden palauttaminen pakottavat meidät tutkimaan mm. seuraavia asioita:

- uusia tai käytöstä poistettuja keinoja perustoimeentulon hankkimiseksi,

- ns. pehmeän teknologian käyttöönottoa teollisuudessa,

- automaation lisäämisen tarpeellisuutta,

- asumismuotoja ja

- ihmisten välistä yhteistyötä ja sosiaalisia suhteita perheessä sekä elin- ja työyhteisöissä.

Samalla saamme mahdollisuuden tarkistaa omaa arvomaailmaamme, joka tällä hetkellä ylikorostaa materialistisia asioita, yksilön tehokkuutta ja voimakasta kaikille aloille ulottuvaa kilpailua, mutta usein unohtaa tekijät, jotka ovat tärkeitä ihmisen henkiselle tasapainolle.

Aikuiskoulutuksen suunnittelussa on erittäin vaikea lähteä määrittelemään koulutustarpeita puhumattakaan koulutuksen sisällöistä ennenkuin edes jonkinlainen kokonaisnäkemys tulevaisuudesta on mudostettu. Opetusministeriön asettama aikuiskoulutusuudistuksen johtoryhmä on viitannut laatimassaan yleissuunnitelmassa tulevaisuuden näkymiin. Olisi toivottavaa, että jatkosuunnittelussa lähdettäisiin paneutumaan perusteellisemmin näihin asioihin. 